\title{
Reaction mechanism studies on atomic layer deposition process of AlF3
}

\section{Nieminen, Heta}

2022-03

Nieminen , H \& Ritala , M 2022 , ' Reaction mechanism studies on atomic layer deposition process of AIF 3 ' , Journal of vacuum science \& technology : an official journal of the American Vacuum Society , vol. 40 , no. 2 , 022401 . https://doi.org/10.1116/6.0001624

http://hdl.handle.net/10138/339323

https://doi.org/10.1116/6.0001624

Downloaded from Helda, University of Helsinki institutional repository.

This is an electronic reprint of the original article.

This reprint may differ from the original in pagination and typographic detail.

Please cite the original version. 


\title{
Reaction mechanism studies on atomic layer deposition process of $\mathrm{AlF}_{3}$
}

\author{
Heta-Elisa Nieminen ${ }^{1}$ and Mikko Ritala ${ }^{1, \text { a) }}$ \\ 1 Department of Chemistry, University of Helsinki, P.O.Box 55, FI-00014 Helsinki, Finland \\ a) mikko.ritala@helsinki.fi
}

\begin{abstract}
In this work, the reaction mechanism in the atomic layer deposition (ALD) process of $\mathrm{AlF}_{3}$ thin films is studied with in situ quartz crystal microbalance (QCM) and quadrupole mass spectrometer (QMS). The depositions are done with $\mathrm{AlCl}_{3}$ and $\mathrm{TiF}_{4}$ as precursors. Similar to many metal fluoride films deposited by $\mathrm{ALD}$, the growth rate of the $\mathrm{AlF}_{3}$ is strongly temperature dependent. In addition, at low temperatures the growth rate is exceptionally high for a traditional ALD process. In this study, the reasons behind these characteristics are studied and a detailed step-by-step mechanism for the $\mathrm{AlF}_{3}$ film growth process is presented.
\end{abstract}




\section{INTRODUCTION}

Atomic layer deposition (ALD) is a superior thin film deposition technique, which is based on sequential chemical reactions between alternately supplied precursor vapors on a substrate surface. With proper precursors and film growth conditions the reactions are self-limiting and pinhole free films with high purity and excellent uniformity and conformality can be deposited with film thickness control on a monolayer scale. ${ }^{1,2}$ The chemistry between the precursors determines the film growth, so only by studying the surface reactions an ALD process can be truly understood. The best way to study the reactions is to observe the changes of the film surface and the surrounding gas atmosphere already during the growth process. These kind of in situ studies have revealed insights on a wide range of different ALD chemistries, as can be seen on the comprehensive review articles published on the topic. ${ }^{3-5}$

An ALD process for $\mathrm{AlF}_{3}$ using $\mathrm{AlCl}_{3}$ and $\mathrm{TiF}_{4}$ precursors has been published by Mäntymäki et al. ${ }^{6} \mathrm{TiF}_{4}$ as a fluorine source is a less hazardous alternative to the common fluorine ALD precursor of HF. Films were deposited at temperatures from 160 to $340{ }^{\circ} \mathrm{C}$ and good saturative ALD behavior was verified. Films were amorphous below $260{ }^{\circ} \mathrm{C}$ and showed increasing amounts of crystallinity at higher temperatures. They contained only small amount of titanium and chlorine impurities that decreased with increasing temperature so that both were less than 1 at. $\%$ at $280{ }^{\circ} \mathrm{C}$. Earlier reaction mechanism studies on $\mathrm{ALD} \mathrm{AlF}_{3}{ }^{7,8}$ and other metal fluoride films ${ }^{9-11}$ have been done only for processes which use HF, ${ }^{11} \mathrm{HF} /$ pyridine ${ }^{8-10}$ or $\mathrm{SF}_{6}$ plasma $^{7}$ as the fluorine sources.

In addition to the $\mathrm{AlF}_{3}, \mathrm{ALD}$ processes for $\mathrm{LiF}, \mathrm{CaF}_{2}, \mathrm{MgF}_{2}, \mathrm{LaF}_{3}, \mathrm{YF}_{3}$ and $\mathrm{TbF}_{3}$ have been developed by using $\mathrm{TiF}_{4}$ as the fluorine source. ${ }^{12-19}$ The processes are thought 
to rely on a ligand exchange reaction between the metal precursor, usually Mthd, $\mathrm{M}(\mathrm{thd})_{2}$ or $\mathrm{M}(\text { thd })_{3}$ (thd $=\operatorname{bis}\left(2,2,6,6\right.$-tetramethyl-3,5-heptanedionato), ${ }^{12-17,19}$ and $\mathrm{TiF}_{4}$ from which a volatile $\mathrm{Ti}(\text { thd })_{4}$ is formed as a byproduct. Similarly, the overall reaction in the $\mathrm{AlF}_{3}$ process studied in this work has been thought to be a ligand exchange reaction between the metal halide precursors.

In many of the metal fluoride ALD processes the growth rates have been noticed to be strongly temperature dependent and exceptionally high at low deposition temperatures. ${ }^{6,13-16}$ This was the case also for the $\mathrm{AlCl}_{3}$ and $\mathrm{TiF}_{4}$ process for $\mathrm{AlF}_{3}$ films where the growth rate decreased from $3 \AA$ /cycle to $0.3 \AA$ /cycle as the deposition temperature was increased from 160 to $340{ }^{\circ} \mathrm{C}{ }^{6}$ The mechanism proposed for explaining the exceptionally high growth rate is that during each pulse the precursors not only react with the functional groups on the surface, but also adsorb onto the freshly formed film. This kind of double monolayer type of growth can also make the process strongly temperature dependent, because the molecular adsorption is a reversible process unlike the common ligand exchange reactions in ALD. Herein we study the growth mechanism of $\mathrm{AlF}_{3}$ to increase the understanding on this kind of reaction mechanisms.

The overall reaction is proposed to be a ligand exchange reaction between $\mathrm{AlCl}_{3}$ and $\mathrm{TiF}_{4}$, which releases $\mathrm{TiCl}_{4}$ as a gaseous byproduct and deposits $\mathrm{AlF}_{3}$ film (reaction 1).

$$
4 \mathrm{AlCl}_{3}(\mathrm{~g})+3 \mathrm{TiF}_{4}(\mathrm{~g}) \rightarrow 4 \mathrm{AlF}_{3}+3 \mathrm{TiCl}_{4}
$$

The reaction can proceed through a few possible routes. Either $\mathrm{AlCl}_{3}$ adsorbs on $\mathrm{AlF}_{3}$ surface without reaction (reaction 2) and $\mathrm{AlF}_{3}$ and $\mathrm{TiCl}_{4}$ form only during the $\mathrm{TiF}_{4}$ pulse (reaction 3), or vice versa (reactions 4-5). 


$$
\begin{aligned}
& 4 \mathrm{AlCl}_{3}(\mathrm{~g}) \rightarrow 4 \mathrm{AlCl}_{3}(\text { ads. }) \\
& 4 \mathrm{AlCl}_{3}(\text { ads. })+3 \mathrm{TiF}_{4}(\mathrm{~g}) \rightarrow 4 \mathrm{AlF}_{3}(\mathrm{~s})+3 \mathrm{TiCl}_{4}(\mathrm{~g}) \\
& 3 \mathrm{TiF}_{4}(\text { ads. })+4 \mathrm{AlCl}_{3}(\mathrm{~g}) \rightarrow 4 \mathrm{AlF}_{3}(\mathrm{~s})+3 \mathrm{TiCl}_{4}(\mathrm{~g}) \\
& 4 \mathrm{AlF}_{3}(\mathrm{~s})+3 \mathrm{TiF}_{4}(\mathrm{~g}) \rightarrow 4 \mathrm{AlF}_{3}(\mathrm{~s})+3 \mathrm{TiF}_{4} \text { (ads.) }
\end{aligned}
$$

Another option is that $\mathrm{AlF}_{3}$ and $\mathrm{TiCl}_{4}$ are formed during both precursor pulses. In that case $x$ amount of $\mathrm{TiCl}_{4}$ is released during the $\mathrm{AlCl}_{3}$ pulse (reaction 6) and the rest during the $\mathrm{TiF}_{4}$ pulse (reaction 7).

$$
\begin{aligned}
& x \mathrm{TiF}_{4}(\text { ads. })+4 \mathrm{AlCl}_{3}(\mathrm{~g}) \rightarrow 4 \mathrm{~F}_{x} \mathrm{AlCl}_{3-x}(\text { ads. })+x \mathrm{TiCl}_{4}(\mathrm{~g}) \\
& 4 \mathrm{~F}_{x} \mathrm{AlCl}_{3-x}(\text { ads. })+3 \mathrm{TiF}_{4}(\mathrm{~g}) \rightarrow 4 \mathrm{AlF}_{3}(\mathrm{~s})+3-x \mathrm{TiCl}_{4}(\mathrm{~g})+x \mathrm{TiF}_{4} \text { (ads.) (7) }
\end{aligned}
$$

Formation of mixed halides, such as $\mathrm{TiFCl}_{3}, \mathrm{TiF}_{2} \mathrm{Cl}_{2}$ and $\mathrm{TiF}_{3} \mathrm{Cl}$, is also possible if all the ligands do not exchange in the reaction.

\section{EXPERIMENTAL}

The depositions were done in a F120 SAT flow-type ALD reactor by ASM Microchemistry Ltd. to which an in situ quartz crystal microbalance (QCM) and quadrupole mass spectrometer (QMS) are attached. The details of this unique ALD reactor are described elsewhere. ${ }^{20}$ The deposition area of the reactor is enlarged compared to a regular F120 ALD reactor to ensure high enough amount of byproducts for detection by QMS. During the measurements the deposition chamber is loaded with glass 
substrates so that overall the substrates and the glass walls make an area of $3500 \mathrm{~cm}^{2}{ }^{20}$ The pressure drop from the working pressure of the ALD reactor (1-5 mbar) to the required pressure in the QMS chamber (around $10^{-5} \mathrm{mbar}$ ) is done by differential pumping through a $150 \mu \mathrm{m}$ orifice. QMS measurements were done with a Hiden HAL/3F 501RC mass spectrometer using an ionization energy of $70 \mathrm{eV}$. The reference mass spectra are from NIST Mass Spectrometry Data Center. ${ }^{21}$ The QCM is placed in between the glass substrates and the QMS inlet, and the measurements are done on a gold coated quartz crystal with a Maxtek TM 400 with a sampling rate of $20 \mathrm{~Hz}$. Before the measurements a thin layer of $\mathrm{AlF}_{3}$ was deposited on the gold coated crystal.

The depositions were done at the temperature range of $160-320{ }^{\circ} \mathrm{C}$ using $\mathrm{AlCl}_{3}$ (Acros Organics, 99\%) and $\mathrm{TiF}_{4}$ (Strem Chemicals, Inc. $98 \%$ ) as precursors. Both precursors were heated in open glass boats inside the reactor and pulsed by inert gas valving to the reaction chamber. The sublimation temperature of $\mathrm{AlCl}_{3}$ was $90{ }^{\circ} \mathrm{C}$ and that of $\mathrm{TiF}_{4} 140{ }^{\circ} \mathrm{C}$.

\section{RESULTS AND DISCUSSION}

In the original paper by Mäntymäki et al, it was noted that the growth rate of $\mathrm{AlF}_{3}$ in the $\mathrm{AlCl}_{3}-\mathrm{TiF}_{4}$ process is strongly temperature dependent and at low temperatures exceptionally high for an ALD process, around $3 \AA$ /cycle at $160{ }^{\circ} \mathrm{C} .{ }^{6}$ The suggested reason for the unusual growth rate is that at low temperatures the precursors would not only react with the surface groups but also adsorb onto the new film formed. ${ }^{6}$ At higher temperatures the adsorption would rapidly decrease, thereby explaining the strong 
temperature dependence of the growth rate. The question is that which precursor, or both, would be adsorbing this way.

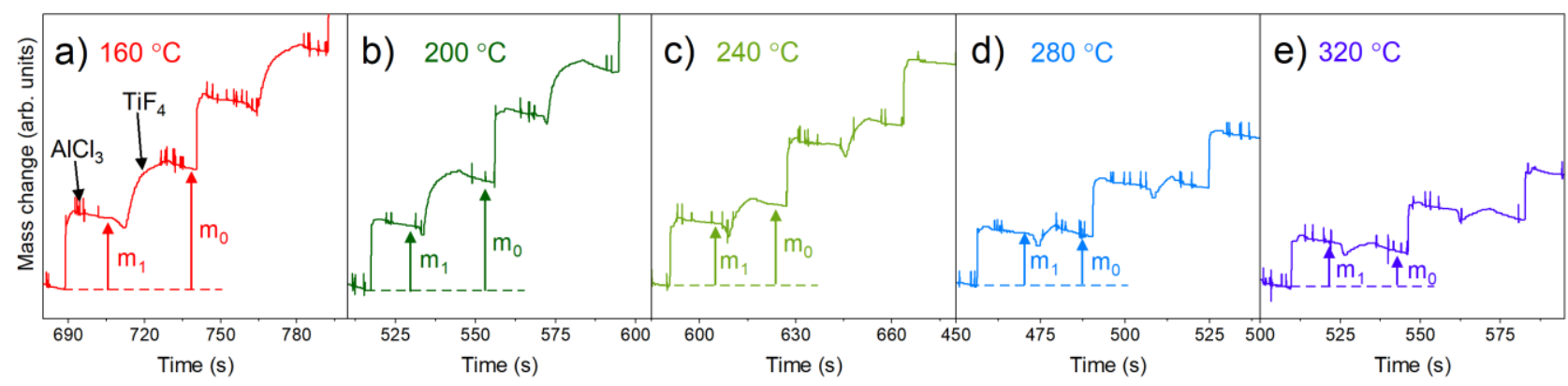

FIG. 1. QCM close up on two ALD cycles of $\mathrm{AlF}_{3}$ at deposition temperatures a) $160{ }^{\circ} \mathrm{C}$, b) $200{ }^{\circ} \mathrm{C}$, c) $240{ }^{\circ} \mathrm{C}$, d) $280{ }^{\circ} \mathrm{C}$ and e) $320{ }^{\circ} \mathrm{C}$.

Mass changes during the deposition of $\mathrm{AlF}_{3}$ were measured with $\mathrm{QCM}$ at each selected temperature (Figure 1a-e). The mass increase during the $\mathrm{AlCl}_{3}$ pulse is sharp throughout the whole temperature range, and only a slight decrease in $\mathrm{m}_{1}$, measured after the following purge, was observed at $320{ }^{\circ} \mathrm{C}$ (Figure 1e). The mass change during the $\mathrm{TiF}_{4}$ pulse on the other hand is clearly temperature dependent. At low deposition temperatures, from 160 to $240{ }^{\circ} \mathrm{C}$, the mass increases also during the $\mathrm{TiF}_{4}$ pulse (Figure 1a-c). At higher temperatures $\left(>240{ }^{\circ} \mathrm{C}\right)$ the mass increase during the $\mathrm{TiF}_{4}$ pulse is much lower and the overall mass change after one whole ALD cycle ( $\left.\mathrm{m}_{0}\right)$ is on the same level (Figure 1d) or even lower (Figure 1e) than after the $\mathrm{AlCl}_{3}$ pulse and purge $\left(\mathrm{m}_{1}\right)$. As a result, $\mathrm{m}_{0}$ that represents the growth rate is strongly temperature dependent (Figure 2) similar to the results in the work of Mäntymäki et al. ${ }^{6}$

These results imply that molecular adsorption of $\mathrm{TiF}_{4}$ on $\mathrm{AlF}_{3}$ is taking place at low temperatures, and this adsorption decreases as the temperature is increased. The mass change during the $\mathrm{AlCl}_{3}$ pulse is less temperature dependent than that during the $\mathrm{TiF}_{4}$ 
pulse, hence no molecular $\mathrm{AlCl}_{3}$ adsorption on $\mathrm{AlF}_{3}$ is suggested to occur. The slight decrease of $\mathrm{m}_{1}$ at higher temperatures presumably originates from the decreased amount of the reactive $\mathrm{TiF}_{4}$ molecules on the surface.

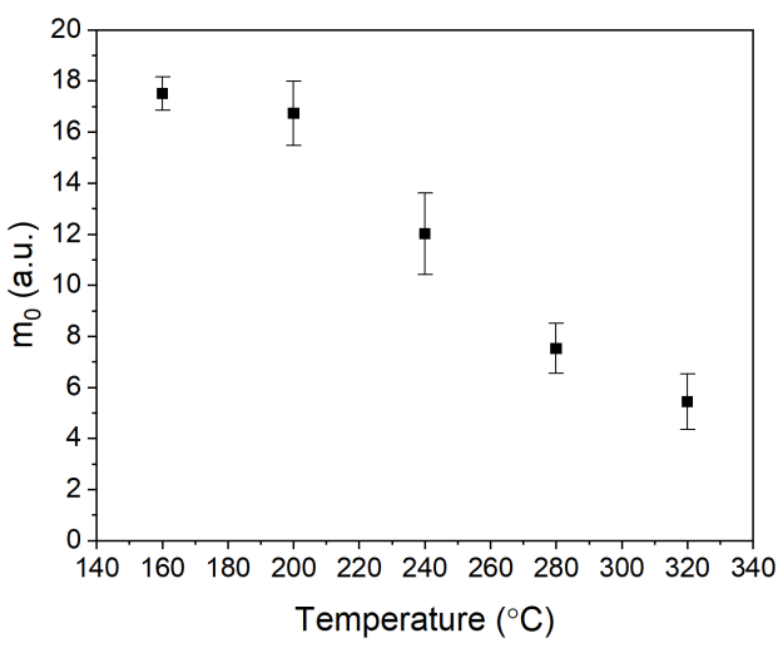

FIG. 2. The mass increase after one whole ALD cycle (mo) as a function of the deposition temperature.

The formation of $\mathrm{TiCl}_{4}$ as a byproduct was clearly detected with QMS at each measured temperature (Figure 3a). Several $\mathrm{m} / \mathrm{z}$ values from the fragmentation pattern of $\mathrm{TiCl}_{4}$ were observed (Table I) and the intensities of the measured fragments are in accordance with the reference mass spectrum. ${ }^{21-23}$ Closer consideration is given for $\mathrm{m} / \mathrm{z}=$ 153 because it has the highest intensity in the mass spectrum of $\mathrm{TiCl}_{4}$. In the measurements shown in Figure $3 \mathrm{a}, \mathrm{TiF}_{4}$ is pulsed alone prior to the ALD sequence for reference to see if certain $\mathrm{m} / \mathrm{z}$ would originate from the precursor itself. Similar reference pulsing was done for $\mathrm{AlCl}_{3}$ after the ALD pulses. It was noticed with QCM that at lower temperatures $\mathrm{TiF}_{4}$ needs higher dose, i.e. longer pulse time to saturate the surface than at high temperatures, which is why the cycling times vary in Figure 3a. 
Fragments corresponding to other possible reaction byproducts, i.e. mixed halides $\mathrm{TiCl}_{3} \mathrm{~F}, \mathrm{TiCl}_{2} \mathrm{~F}_{2}$ and $\mathrm{TiClF}_{3}$, were followed as well (Table I). The fragmentation patterns of these halides overlap to some extent with each other and with $\mathrm{TiCl}_{4}$. However, no ions corresponding specifically to the mixed halides were visible and hence the recurring $\mathrm{m} / \mathrm{z}$ are assigned to $\mathrm{TiCl}_{4}$ and no other byproduct is identified in the process. However, the lower the vapor pressure is for a suggested byproduct, the more difficult it is to detect, so some formation of mixed halides cannot be absolutely excluded. The major byproduct in the process is anyway $\mathrm{TiCl}_{4}$.

$\mathrm{TiCl}_{4}$ formation was especially clear during the $\mathrm{AlCl}_{3}$ pulse at each temperature (Figure $3 b$ ). This indicates that after the $\mathrm{TiF}_{4}$ pulse the surface is always $-\mathrm{TiF}_{\mathrm{x}}$ terminated, even though $\mathrm{TiF}_{4}$ adsorbs on to the $\mathrm{AlF}_{3}$ surface less at high temperatures as discussed earlier. As less $-\mathrm{TiF}_{\mathrm{x}}$ groups exist on the surface at higher temperatures, not all the chlorides in $\mathrm{AlCl}_{3}$ are able to exchange and form $\mathrm{TiCl}_{4}$ already during the $\mathrm{AlCl}_{3}$ pulse. The unreacted chlorides remaining on the surface react during the $\mathrm{TiF}_{4}$ pulse, which is observed in QMS as a release of $\mathrm{TiCl}_{4}$ also during the $\mathrm{TiF}_{4}$ pulse at temperatures $\geq 200{ }^{\circ} \mathrm{C}$. At the low temperature of $160{ }^{\circ} \mathrm{C}$ almost all $\mathrm{TiCl}_{4}$ is formed during the $\mathrm{AlCl}_{3}$ pulse, presumably because the surface contains a high amount of $\mathrm{TiF}_{4}$ in the beginning of the $\mathrm{AlCl}_{3}$ pulse. This deduction based on the QMS observations is in line with the QCM results which also implied that $\mathrm{AlCl}_{3}$ does not adsorb on $\mathrm{AlF}_{3}$ similarly as $\mathrm{TiF}_{4}$ does. 

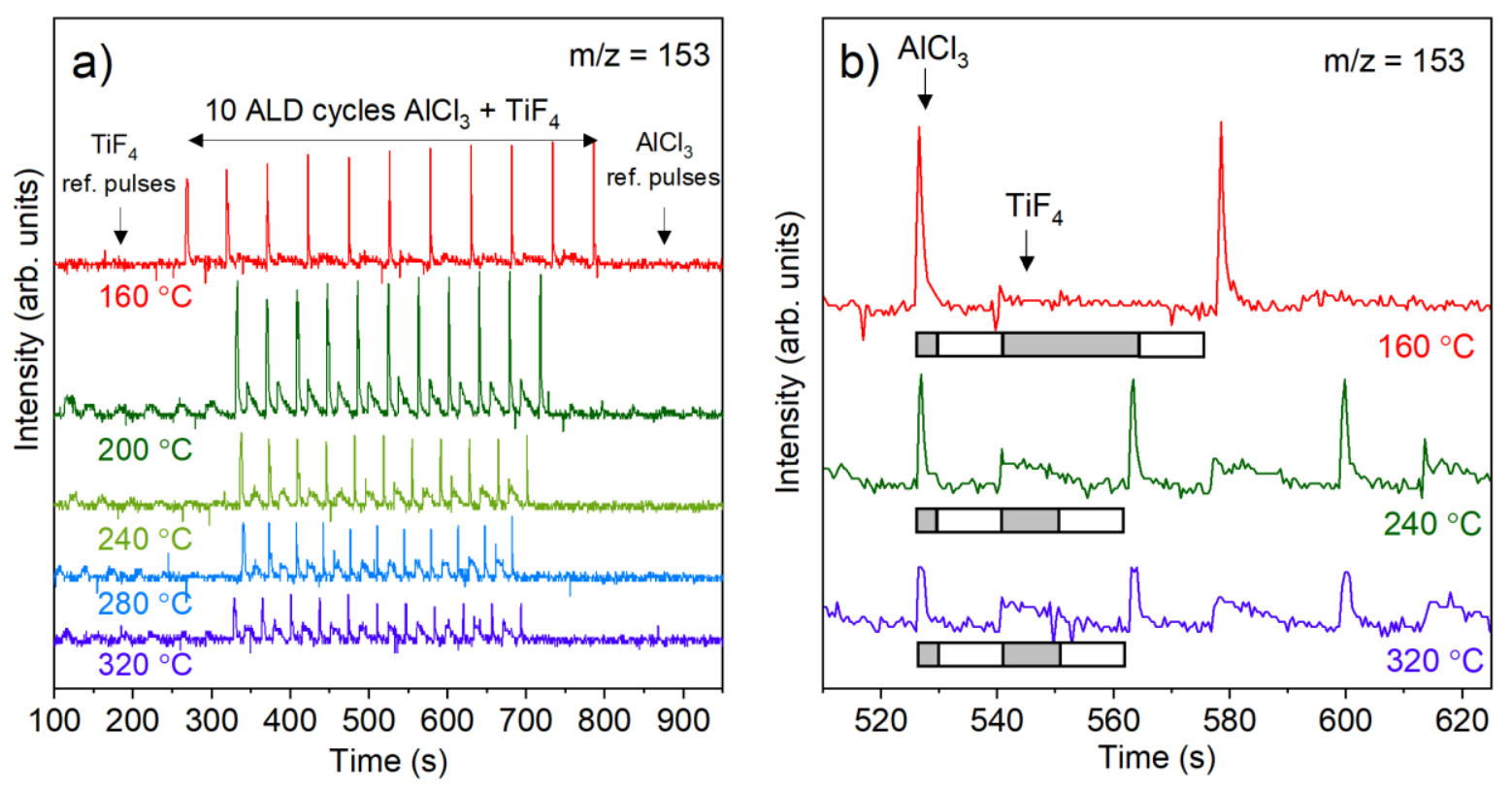

FIG. 3. a) QMS measurements of $\mathrm{m} / \mathrm{z}=153\left(\mathrm{TiCl}_{3}{ }^{+}\right)$at each deposition temperature and b) a close up on measurements done at 160,240 and $320{ }^{\circ} \mathrm{C}$.

TABLE I. The measured $\mathrm{m} / \mathrm{z}$ values, observations and possible fragments. The measurements were done at $240{ }^{\circ} \mathrm{C}$.

$\mathrm{m} / \mathrm{z}$ Observation Fragment $\mathrm{m} / \mathrm{z}$ Observation Fragment

\begin{tabular}{llllll}
\hline 48 & yes & {$\left[{ }^{48} \mathrm{Ti}^{+}\right.$} & 153 & yes & {$\left[{ }^{48} \mathrm{Ti}^{35} \mathrm{Cl}_{3}\right]^{+}$} \\
100 & no & {$\left[{ }^{27} \mathrm{Al}^{35} \mathrm{Cl}^{19} \mathrm{~F}_{2}\right]^{+}$} & 155 & yes & {$\left[{ }^{48} \mathrm{Ti}^{35} \mathrm{Cl}_{2}{ }^{37} \mathrm{Cl}\right]^{+}$} \\
102 & no & {$\left[{ }^{48} \mathrm{Ti}^{35} \mathrm{Cl}^{19} \mathrm{~F}\right]^{+}$} & 156 & no & {$\left[{ }^{48} \mathrm{Ti}^{35} \mathrm{Cl}_{2}{ }^{19} \mathrm{~F}_{2}\right]^{+}$} \\
116 & no & {$\left[{ }^{27} \mathrm{Al}^{35} \mathrm{Cl}_{2}{ }^{19} \mathrm{~F}^{+}\right.$} & 157 & yes & {$\left[{ }^{48} \mathrm{Ti}^{35} \mathrm{Cl}^{37} \mathrm{Cl}_{2}\right]^{+}$} \\
118 & yes & {$\left[{ }^{48} \mathrm{Ti}^{35} \mathrm{Cl}_{2}\right]^{+}$} & 172 & no & {$\left[{ }^{48} \mathrm{Ti}^{35} \mathrm{Cl}_{3}{ }^{19} \mathrm{~F}^{+}\right.$} \\
120 & no & {$\left[{ }^{48} \mathrm{Ti}^{35} \mathrm{Cl}^{37} \mathrm{Cl}\right]^{+}$} & 188 & yes & {$\left[{ }^{48} \mathrm{Ti}^{35} \mathrm{Cl}_{4}\right]^{+}$} \\
121 & no & {$\left[{ }^{48} \mathrm{Ti}^{35} \mathrm{Cl}^{19} \mathrm{~F}_{2}\right]^{+}$} & 190 & yes & {$\left[{ }^{48} \mathrm{Ti}^{35} \mathrm{Cl}_{3}{ }^{37} \mathrm{Cl}^{+}\right.$} \\
137 & no & {$\left[{ }^{48} \mathrm{Ti}^{35} \mathrm{Cl}^{19} \mathrm{~F}^{+}\right.$} & 192 & yes & {$\left[{ }^{48} \mathrm{Ti}^{35} \mathrm{Cl}^{37} \mathrm{Cl}_{2}\right]^{+}$} \\
140 & no & {$\left[{ }^{48} \mathrm{Ti}^{35} \mathrm{Cl}^{19} \mathrm{~F}_{3}\right]^{+}$} & & & \\
\hline \hline
\end{tabular}


According to the results presented in this study, during the first precursor pulse of the $\mathrm{ALD}$ cycle $\mathrm{AlCl}_{3}$ goes through a ligand exchange reaction with $\mathrm{TiF}_{4}$ terminated surface resulting in $\mathrm{F}_{\mathrm{x}} \mathrm{AlCl}_{3-\mathrm{x}}$ surface species and formation of gas phase byproduct $\mathrm{TiCl}_{4}$ (reaction 6). The reaction is observed in QCM as a sharp mass increase during the $\mathrm{AlCl}_{3}$ pulse and in QMS as a very clear release of $\mathrm{TiCl}_{4}$. During the second precursor pulse of the ALD cycle $\mathrm{TiF}_{4}$ then reacts with the remaining chlorides on the $\mathrm{F}_{\mathrm{x}} \mathrm{AlCl}_{3-\mathrm{x}}$ surface forming $\mathrm{AlF}_{3}$. In addition, $\mathrm{TiF}_{4}$ adsorbs on to the $\mathrm{AlF}_{3}$ surface recreating $\mathrm{TiF}_{4}$ terminated surface and the next ALD cycle is ready to begin (reaction 7). As was seen with QCM, the adsorption of $\mathrm{TiF}_{4}$ is strongly temperature dependent, which leads to the strong temperature dependence of the growth rate of the process.

At lower temperatures more $\mathrm{TiF}_{4}$ adsorbs on $\mathrm{AlF}_{3}$ and almost no $\mathrm{TiCl}_{4}$ is formed during the $\mathrm{TiF}_{4}$ pulse. This means that at $160{ }^{\circ} \mathrm{C} x$ in reactions 6-7 should be close to 3 . When the temperature increases, less $\mathrm{TiF}_{4}$ is adsorbed, and $x$ decreases. The reaction coefficient $x$ is estimated from the QCM results using the mass change ratio $\mathrm{m}_{1} / \mathrm{m}_{0}$, and from the QMS results by comparing the amounts of $\mathrm{TiCl}_{4}$ released during the $\mathrm{AlCl}_{3}$ pulse (A) and the $\mathrm{TiF}_{4}$ pulse $(B)$.

Based on the reactions 6 and 7, after the $\mathrm{AlCl}_{3}$ pulse and purge the mass change of the film is $\mathrm{m}_{1}=4 * \mathrm{~m}\left(\mathrm{AlCl}_{3}\right)-x * \mathrm{~m}\left(\mathrm{TiCl}_{4}\right)$. After one complete ALD cycle the mass increase should be $\mathrm{m}_{0}=4 * \mathrm{~m}\left(\mathrm{AlF}_{3}\right)$. The masses can be replaced with the corresponding molar masses $\left(\mathrm{M}\left(\mathrm{AlCl}_{3}\right)=133.3 \mathrm{~g} / \mathrm{mol}, \mathrm{M}\left(\mathrm{TiCl}_{4}\right)=189.7 \mathrm{~g} / \mathrm{mol}\right.$ and $\mathrm{M}\left(\mathrm{AlF}_{3}\right)=84.0$ $\mathrm{g} / \mathrm{mol})$. From the ratio $\mathrm{m}_{1} / \mathrm{m}_{0}$

$$
\frac{\mathrm{m}_{1}}{\mathrm{~m}_{0}}=\frac{4 * \mathrm{M}\left(\mathrm{AlCl}_{3}\right)-x * \mathrm{M}\left(\mathrm{TiCl}_{4}\right)}{4 * \mathrm{M}\left(\mathrm{AlF}_{3}\right)}
$$


$x$ is solved as

$$
x=\frac{4 * \mathrm{M}\left(\mathrm{AlCl}_{3}\right)-4 * \mathrm{M}\left(\mathrm{AlF}_{3}\right) * \frac{\mathrm{m}_{1}}{\mathrm{~m}_{0}}}{\mathrm{M}\left(\mathrm{TiCl}_{4}\right)} .
$$

In the reactions 6 and 7, $x$ amount of $\mathrm{TiCl}_{4}$ is released during the $\mathrm{AlCl}_{3}$ pulse and 3-x during the $\mathrm{TiF}_{4}$ pulse. In the proportion below (Equation 3) the ratio of these quantities is compared to the intensity ratio of the byproducts observed with QMS. A is the integrated area of $\mathrm{m} / \mathrm{z}=153$ during the $\mathrm{AlCl}_{3}$ pulse and $\mathrm{B}$ the integrated area of $\mathrm{m} / \mathrm{z}=$ 153 during the $\mathrm{TiF}_{4}$ pulse. As already noted, the intensity of $\mathrm{m} / \mathrm{z}=153$ is used because it is the strongest fragment in the $\mathrm{TiCl}_{4}$ mass spectrum.

$$
\frac{A}{B}=\frac{x}{3-x}
$$

from there $x$ can be solved as

$$
x=\frac{3 * \frac{A}{B}}{1+\frac{A}{B}} .
$$

The calculated $\mathrm{m}_{1} / \mathrm{m}_{0}$ and $A / B$ ratios for each measurement temperature and $x$ defined from them are listed in Table II. The trend of decreasing $x$ with increasing temperature is clear for both measurement techniques. The values themselves correspond better at temperatures 200,240 and $280{ }^{\circ} \mathrm{C}$ than they do at either extremes of 160 and 320 ${ }^{\circ} \mathrm{C}$. However, these measurements must be considered as only estimations to support the qualitative observations on the mechanism. For comparison $\mathrm{m}_{1} / \mathrm{m}_{0}$ for reactions 2 and 3 would be 1.6 , and for reactions 4 and $5 \mathrm{~m}_{1} / \mathrm{m}_{0}$ would be -0.1 . 
TABLE II. The mass change ratios $\mathrm{m}_{1} / \mathrm{m}_{0}$, the ratios of released amount of $\mathrm{TiCl}_{4} A / B$ and $x$ defined from QCM and QMS results at each temperature.

\begin{tabular}{lllll}
$T\left({ }^{\circ} \mathrm{C}\right)$ & $\mathrm{m}_{1} / \mathrm{m}_{0}$ & $x$ according to QCM & $A / B$ & $x$ according to QMS \\
\hline 160 & 0.54 & 1.8 & 4.5 & 2.5 \\
200 & 0.61 & 1.7 & 2.2 & 2.0 \\
240 & 0.80 & 1.4 & 0.86 & 1.4 \\
280 & 1.1 & 0.93 & 0.61 & 1.1 \\
320 & 1.2 & 0.60 & 0.44 & 0.92 \\
\hline \hline
\end{tabular}

\section{IV.SUMMARY AND CONCLUSIONS}

In this work, the reaction mechanism of the ALD process of $\mathrm{AlF}_{3}$ was studied with in situ QCM and QMS. The growth occurs via ligand exchange reaction between $\mathrm{AlCl}_{3}$ and $\mathrm{TiF}_{4}$ forming volatile $\mathrm{TiCl}_{4}$ as a byproduct. No other byproducts were detected. The growth rate of the $\mathrm{AlF}_{3}$ process is strongly temperature dependent, and especially at lower temperatures the growth rate is higher than expected for a traditional ALD process. The high growth rate was found to occur because after reacting with the $\mathrm{F}_{x} \mathrm{AlCl}_{3-x}$ surface created by the previous $\mathrm{AlCl}_{3}$ pulse, $\mathrm{TiF}_{4}$ adsorbs molecularly on the freshly formed $\mathrm{AlF}_{3}$. On contrary to the earlier presumptions, the effect was observed only for $\mathrm{TiF}_{4}$ whereas $\mathrm{AlCl}_{3}$ did not adsorb molecularly on $\mathrm{AlF}_{3}$. $\mathrm{TiF}_{4}$ adsorption was found to be strongly temperature dependent, which leads to the strong temperature dependence of the mass increase during the $\mathrm{TiF}_{4}$ half reaction and thereby to strong temperature dependence of the growth rate. 


\section{ACKNOWLEDGMENTS}

Financial support by Doctoral Programme in Materials Research and Nanosciences (MATRENA) of the University of Helsinki is gratefully acknowledged. The use of ALD center Finland research infrastructure is acknowledged. Mr. Mikko Kaipio is thanked for helpful discussions on the topic.

\section{DATA AVAILABILITY}

The data that is used in this study are available upon request from the corresponding author and from the first author (heta-elisa.nieminen@ helsinki.fi).

\section{REFERENCES}

1. M. Ritala and J. Niinistö Chapter 4: Atomic Layer Deposition. in Chemical Vapour Deposition: Precursors, Processes and Applications (Royal Society of Chemistry, 2008).

2. M. G. Steven Chem. Rev. 110, 111 (2010).

3. K. Knapas and M. Ritala Crit. Rev. Solid State Mater. Sci. 38, 167 (2013).

4. F. Zaera Coord. Chem. Rev. 257, 3177 (2013).

5. N. E. Richey, C. De Paula and S. F. Bent J. Chem. Phys. 152, (2020).

6. M. Mäntymäki, M. J. Heikkilä, E. Puukilainen, K. Mizohata, B. Marchand, J. Räisänen, M.Ritala and M. Leskelä Chem. Mater. 27, 604 (2015).

7. M. F. J. Vos, H. C. M. Knoops, W. M. M. Kessels and A. J. M. MacKusl J. Phys. Chem. C 125, 3913 (2021). 
8. Y. Lee, J. W. DuMont, A. S. Cavanagh, and S. M. George J. Phys. Chem. C 119, 14185 (2015).

9. $\quad$ L. Chen, K. S. Chen, X. Chen, G. Ramirez, Z. Huang, N. R. Geise, H. G.

Steinrück, B. L. Fisher, R. Shahbazian-Yassar, M. F. Toney, M. C. Hersam and J.

W. Elam ACS Appl. Mater. Interfaces 10, 26972 (2018).

10. Y. Lee, H. Sun, M. J. Young, and S. M. George Chem. Mater. 28, 2022 (2016).

11. S. H. Lee, H. H. Park, H. Kim and M. H. Huang Comput. Mater. Sci. 191, 110327 (2021).

12. M. Mäntymäki, J. Hämäläinen, E. Puukilainen, F. Munnik, M. Ritala and M. Leskelä Chem. Vap. Depos. 19, 111 (2013).

13. T. Pilvi, K. Arstila, M. Leskelä and M. Ritala Chem. Mater. 19, 3387 (2007).

14. T. Pilvi, T. Hatanpää, E. Puukilainen, K. Arstila, M. Bischoff, U. Kaiser, N. Kaiser, M. Leskelä and M. Ritala J. Mater. Chem. 17, 5077 (2007).

15. T. Pilvi, E. Puukilainen, K. Arstila, M. Leskelä and M. Ritala Chem. Vap. Depos. 14,85 (2008).

16. T. Pilvi, E. Puukilainen, F. Munnik, M. Leskelä and M. Ritala Chem. Vap. Depos. 15,27 (2009).

17. E. Atosuo, J. Ojala, M. J. Heikkilä, M. Mattinen, K. Mizohata, J. Räisänen, M. Leskelä and M. Ritala J. Vac. Sci. Technol. A 39, 022404 (2021).

18. J. Xie, L. Liao, Y. Gong, Y. Li, F. Shi, A. Pei, J. Sun, R. Zhang, B. Kong, R. Subbaraman, J. Christensen and Y. Cui Sci. Adv. 3, 1 (2017).

19. M. Mäntymäki, J. Hämäläinen, E. Puukilainen, T. Sajavaara, M. Ritala and M. Leskelä Chem. Mater. 25, 1656 (2013). 
20. A. Rahtu and M. Ritala Electrochem. Soc. Proc. 2000-13, (2000).

21. W. E. Wallace 'Mass Spectra' by NIST Mass Spectrometry Data Center. in NIST Chemistry WebBook, NIST Standard Reference Database Number 69 (eds.

Linstrom, P. J. \& Mallard, W. G.) (National Institute of Standards and Technology). doi:https://doi.org/10.18434/T4D303

22. R. Basner, M. Schmidt, K. Becker, V. Tarnovsky, and H. Deutsch, Thin Solid Films 374, 291 (2000).

23. C. M. Reddy and C. C. Amato-Wierda Electrochem. Soc. Proc. 2001-13 


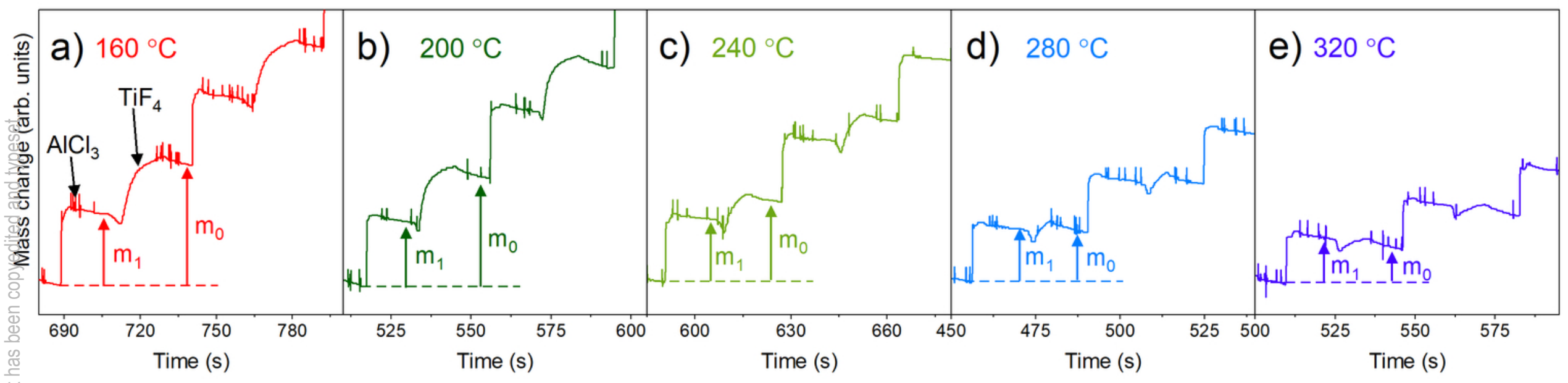




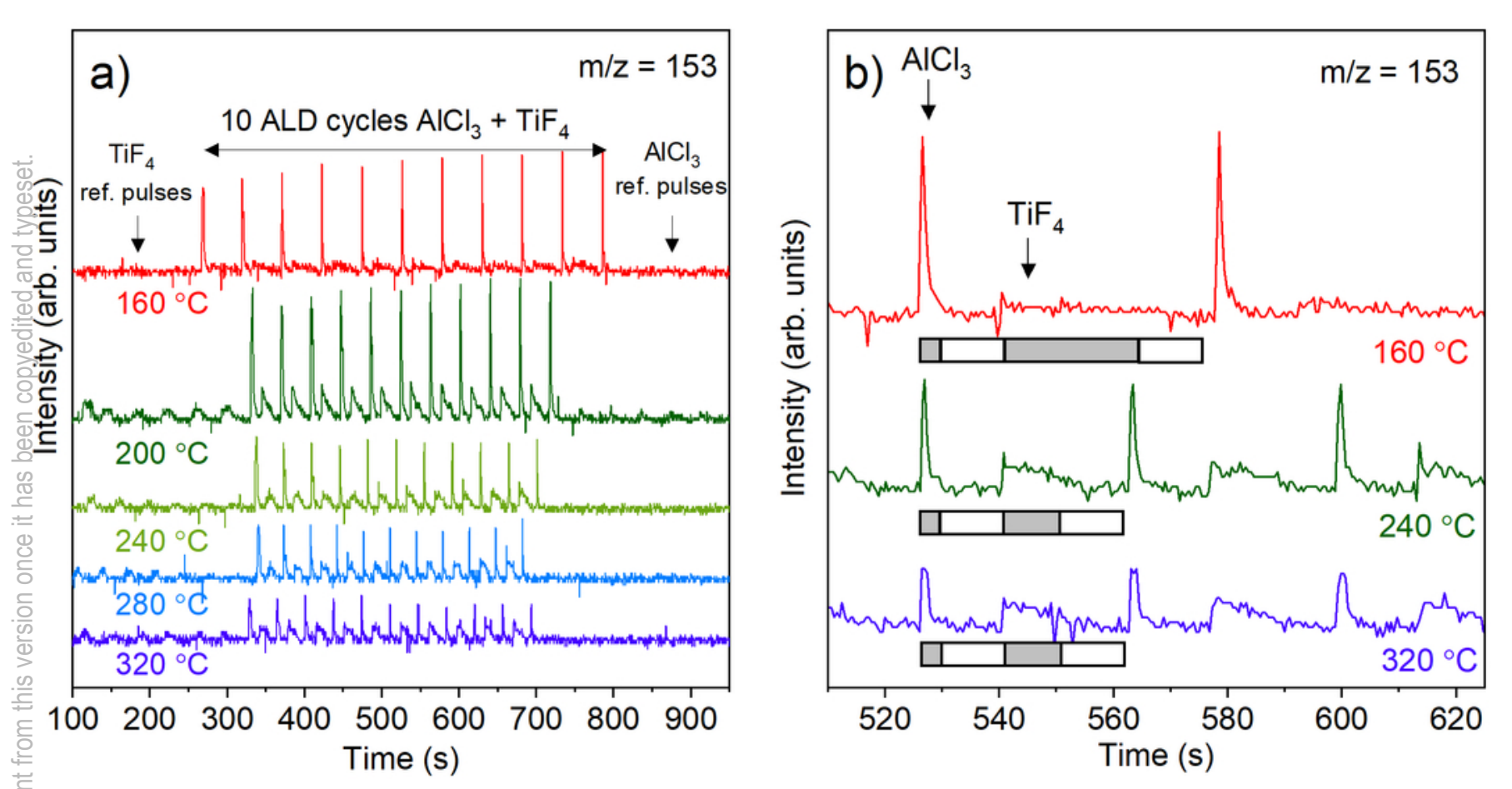

